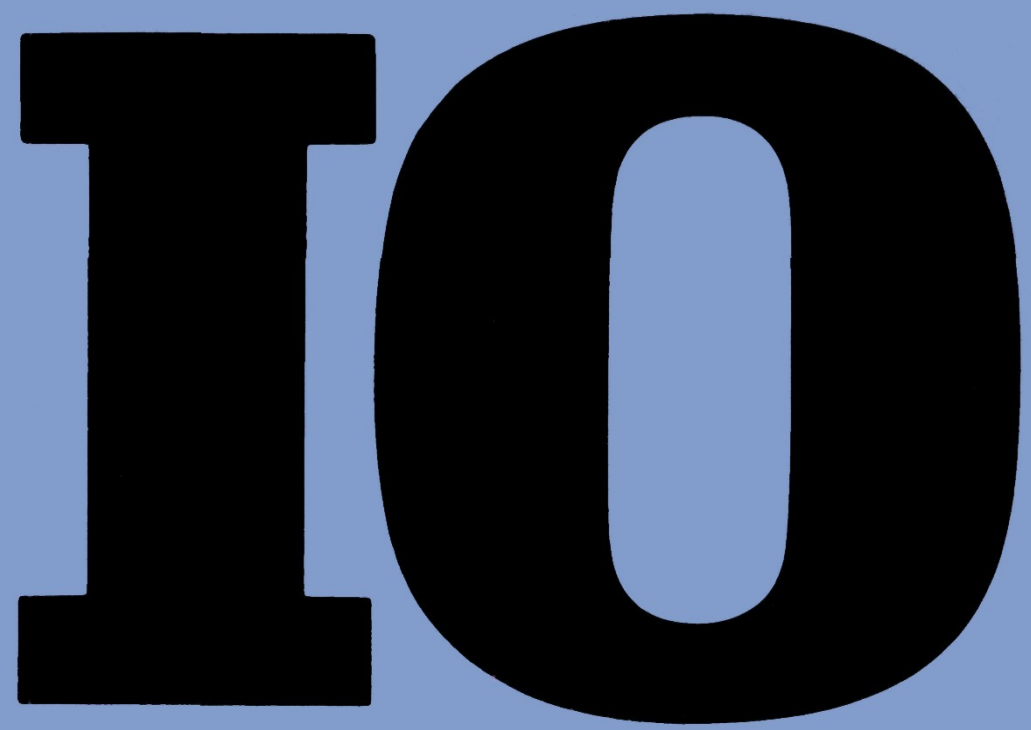

\title{
Intemational Oyganivation
}

Thomas Risse

Communicative Action in World Politics

Deborah Avant

Explaining Change in the Practice of War

Daniel W. Drezner

Bargaining, Enforcement, and Sanctions

Sophie Meunier

European Institutions and EU-U.S. Trade Negotiations

James McCall Smith

The Politics of Dispute Settlement Design 


Emanuel Adler
Robert Bates
Benjamin J. Cohen
George W. Downs
Matthew Evangelista
James Fearon
Martha Finnemore
Jeff Frieden
Geoffrey Garrett
Judith Goldstein
Peter Gourevitch
Miles Kahler
Peter Katzenstein
Robert O. Keohane
Stephen D. Krasner
David A. Lake

Emanuel Adler
Editors

Review Editors

Managing Editor

Judith Goldstein Editorial Board Chair

Charles Lipson Editorial Board

Edward D. Mansfield

Lisa Martin

Helen V. Milner

James Morrow

John Odell

Louis Pauly

Thomas Risse

Ronald Rogowski

Frances Rosenbluth

Kathryn Sikkink

Beth Simmons

Arthur Stein

Janice Stein

Beth V. Yarbrough

Mark W. Zacher

INTERNATIONAL ORGANIZATION invites the submission of original manuscripts on all aspects of world politics and international political economy. Authors should follow the guidelines published annually in the Winter issue. Guidelines also may be found on the World Wide Web at http://mitpress.mit.edu/IO.

Address for submissions:

Lynne Bush

Managing Editor

International Organization

IR/PS

University of California, San Diego

9500 Gilman Drive

La Jolla, CA 92093-0519

Statements and opinions expressed in International Organization are the responsibility of the authors alone and do not imply the endorsement of the Board of Editors, the Board of Trustees of the World Peace Foundation, the University of California, or The MIT Press.

For abstracting listing and price information, please refer to the back of this issue.

Periodicals postage is paid at Boston, Mass., and at additional mailing offices. 


\section{International Organization}

Volume 54, Number 1, Winter 2000

\section{Articles}

"Let's Argue!": Communicative Action in World Politics

Thomas Risse

From Mercenaries to Citizen Armies: Explaining Change in the

Practice of War Deborah Avant

Bargaining, Enforcement, and Multilateral Sanctions: When Is

Cooperation Counterproductive? Daniel W. Drezner

What Single Voice? European Institutions and EU-U.S. Trade

Negotiations Sophie Meunier

The Politics of Dispute Settlement Design: Explaining Legalism

in Regional Trade Pacts James McCall Smith

Guidelines for Contributors 


\section{Contributors}

Deborah Avant is Associate Professor of Political Science and International Affairs at George Washington University, Washington, D.C. She can be reached at avant@gwu.edu.

Daniel W. Drezner is Assistant Professor of Political Science at the University of Chicago, Chicago, Illinois. He can be reached at ddrezner@uchicago.edu.

Sophie Meunier is Visiting Research Fellow at the Center of International Studies and Lecturer in Public and International Affairs, Princeton University, Princeton, New Jersey. She can be reached at smeunier@princeton.edu.

Thomas Risse holds the Joint Chair in International Relations at the Robert Schuman Centre and the Department of Social and Political Sciences of the European University Institute, Florence, Italy. He can be reached at risse@datacomm.iue.it.

James McCall Smith is Assistant Professor of Political Science and International Affairs at George Washington University, Washington, D.C. He can be reached at jaysmith@gwu.edu. 


\title{
Abstracts
}

\author{
"Let's Argue!" Communicative Action in World Politics \\ by Thomas Risse
}

This article introduces a mode of social action and interaction that has so far been largely overlooked in the U.S.-dominated international relations debate between rational choice and social constructivism that focuses mainly on the differences between instrumental rationality and norm-guided behavior. Drawing on insights from a theoretical debate within the Germanspeaking international relations community, I suggest that actors have a third mode of social action at their disposal: arguing and deliberating about the validity claims inherent in any communicative statement about identities, interests, and the state of the world. Arguing and truth-seeking behavior presuppose that actors no longer hold fixed interests during their communicative interaction but are open to persuasion, challenges, and counterchallenges geared toward reaching a reasoned consensus. The preconditions for argumentative rationality, particularly a "common lifeworld" and the mutual recognition of speakers as equals in a nonhierarchical relationship, are more common in international relations than is usually assumed. Arguing processes are more likely to occur the more actors are uncertain about their interests and even identities, the less they know about the situation in which they find themselves and the underlying "rules of the game," and the more apparently irreconcilable differences prevent them from reaching an optimal rather than a merely satisfactory solution for a widely perceived problem ("problem solving"). Moreover, arguing is likely to increase the influence of the materially less powerful, be it small states or nonstate actors such as INGOs. I illustrate these claims empirically with two plausibility probes. The first concerns the East-West talks leading to a negotiated settlement of the Cold War in Europe and German unification within NATO. The second case focuses on the implementation of international human rights norms into domestic practices of Third World states.

\section{From Mercenary to Citizen Armies: Explaining Change in the Practice of War by Deborah Avant}

Mercenary armies went out of style in the nineteenth century; it became common sense that armies should be staffed with citizens. I argue that even though realist explanations focusing on the fighting prowess of citizen armies and sociological explanations focusing on the fit between citizen armies and prevailing ideas can rationalize this change, they cannot explain it. I examine, instead, the politics behind the new reliance on citizen armies and argue that material and ideational turmoil provided important antecedent conditions for change. Beyond this, 
individual states were more likely to move toward citizen armies when they had been defeated militarily and when the ruling coalition was split or indifferent about the reforms tied to citizen armies. Finally, the apparent success of citizen armies in France and then Prussia made domestic conditions for reform easier to obtain in other countries, reinforcing the likelihood that the solution would be replicated. I conclude that the interaction between domestic politics and path dependency provides a promising source of hypotheses for explaining the conditions under which new ways of war emerge and spread.

\title{
Bargaining, Enforcement, and Multilateral Economic Sanctions: When Is Cooperation Counterproductive?
}

\author{
by Daniel W. Drezner
}

Scholars and policymakers generally assume that multilateral cooperation is a necessary condition for economic sanctions to be of any use. However, previous statistical tests of this assumption have shown that sanctions are more successful with lower levels of cooperation. This puzzle calls into question established theories of economic statecraft as well as theories of international cooperation. In this article I test possible explanations for the ineffectiveness of multilateral cooperation on sanctions events using James Fearon's (1998) breakdown of cooperation into bargaining and enforcement phases as a framework for discussion. The empirical results show that when multilateral economic sanctions fail, their failure is due to enforcement, not bargaining problems. Without the support of an international organization, cooperating states backslide from promises of cooperation. Backsliding occurs because of domestic political pressures and uncertainty about the intentions of the other sanctioning countries; backsliding causes an initial burst of cooperative behavior to decay over time. Without institutional support, cooperation is worse than useless-it is counterproductive. This result suggests that international cooperation is a more fragile equilibrium than previously thought but undercuts realist arguments that international organizations are unimportant.

\section{What Single Voice? European Institutions and EU-U.S. Trade Negotiations by Sophie Meunier}

The member states of the European Union (EU) have transferred their sovereignty over trade policymaking to the supranational level. When entering into trade negotiations with third countries, they must first reach a common bargaining position among themselves and later defend that position with a "single voice" at the international table. How do the institutional rules, through which the fifteen different voices are aggregated into a single one, affect international outcomes? Differentiating between a "conservative" and a "reformist" negotiating context, I argue that voting rules and negotiating competence in the EU determine both the probability that the negotiating parties conclude an international agreement and the substantive outcome of the negotiations. The recent EU-U.S. trade negotiations on agriculture, public procurement, and open skies are all evidence that, for a given distribution of preferences, internal EU institutional mechanisms affect the outcomes of international trade agreements.

\section{The Politics of Dispute Settlement Design: Explaining Legalism in Regional Trade Pacts} by James McCall Smith

Dispute settlement mechanisms in international trade vary dramatically from one agreement to another. Some mechanisms are highly legalistic, with standing tribunals that resemble national 
courts in their powers and procedures. Others are diplomatic, requiring only that the disputing countries make a good-faith effort to resolve their differences through consultations. In this article I seek to account for the tremendous variation in institutional design across a set of more than sixty post-1957 regional trade pacts. In contrast to accounts that emphasize the transaction costs of collective action or the functional requirements of deep integration, I find that the level of legalism in each agreement is strongly related to the level of economic asymmetry, in interaction with the proposed depth of liberalization, among member countries. 